\title{
The production and water extraction of lucerne and ryegrass under different irrigation frequencies on a shallow soil.
}

\author{
A.J. MICHEL, H.E. BROWN, E.I. TEIXEIRA, E.D. MEENKEN, S. MALEY, M.J. GEORGE and R.N. GILLESPIE \\ The New Zealand Institute for Plant and Food Research Limited, Lincoln, New Zealand
}

Alexandre.Michel@plantandfood.co.nz

\begin{abstract}
A field experiment was conducted on a shallow soil (low plant available water holding capacity) at Lincoln (Canterbury, New Zealand) to compare the biomass production of lucerne (Medicago sativa L.) and perennial ryegrass (Lolium perenne) under four different irrigation frequencies: (T1) replacing water use (WU) twice a week (replicating centre pivot rewetting frequencies); (T2) replacing WU fortnightly (replicating travelling irrigator); (T3) replacing WU every 3 weeks (replicating border dyke); (T4) nil irrigation (rain fed only). Soil water content was measured hourly at $0-30$ $\mathrm{cm}$ depth and fortnightly at $0-150 \mathrm{~cm}$ depth. Plots were sown in March 2011 and defoliated on eight (ryegrass) and five to six (lucerne) occasions each season between September 2011 and May 2014. Annual biomass production during the first year was highest for ryegrass under each treatment because the lucerne crops were still establishing. During the second and third year of experimentation ryegrass yielded higher or similar to lucerne under the irrigated treatments (T1, T2 and T3). This was attributed to a decline in lucerne stands due to weed pressure. It is important to note that the ryegrass crop has received $250-700 \mathrm{~kg} \mathrm{~N} / \mathrm{ha}$ per year depending on the irrigation treatment. Under dry conditions (T4) ryegrass yielded more than lucerne in both year 2 and 3 . This result contrasts the literature and is attributed to the greater capacity of ryegrass to grow in cooler season and the stony sub-soil meaning lucerne received no summer yield advantage from its deep tap root.
\end{abstract}

Key words: Medicago sativa L., Lolium perenne, biomass, water extraction, irrigation frequency

\section{Introduction}

A large extent of Canterbury's agricultural land is characterised by shallow and drought-prone soils (Moot et al. 2010). The recent expansion towards large-scale, intensive dairy farming in the region over the last decade has driven a rapid development and expansion of irrigation. The Canterbury region is historically subjected to dry summer spells and these are projected to become more frequent and intense in the future (Salinger 2003). Under dry conditions pasture production is limited by water availability, and there is an increasing pressure on irrigation water resources. Thus, it is important to develop irrigation management practices that increase utilisation efficiency of water (Hayman 1985; Moot et al. 2008; Moot et al. 2010). The optimisation of irrigation frequency and application amounts, and the choice of more water efficient crops are typical examples of such management interventions. For example, the use of lucerne (Medicago sativa L.) in dryland grazing systems has been shown to increase yields in comparison to the more commonly used ryegrass pastures (Lolium perenne) in New Zealand deep soils (Douglas 1986; Moot 2012; White 1982). The main adaptive mechanism is the deeper root system of lucerne that enables access to larger volumes of soil water (Sheaffer et al. 1988). However, previous studies were mainly performed on deep soils with high plant available water holding capacity (PAWHC). It is unclear how these crops compare when grown in shallow soils and under different irrigation frequencies.

In this study, we compare the annual biomass production, water extraction and water use efficiency of lucerne and ryegrass on a shallow stony soil with low PAWHC and under different irrigation regimes. This comparison will help understand the influence of irrigation management on pasture production in Canterbury.

\section{Materials and methods}

\section{Experimental site and crop establishment}

This experiment was established at the AgResearch farm, Lincoln, Canterbury $\left(43^{\circ} 37^{\prime} 16^{\prime \prime} \mathrm{S}\right.$ and $\left.172^{\circ} 28^{\prime} 15^{\prime \prime} \mathrm{E}\right)$, on an Eyre silt loam soil with $30 \mathrm{~cm}$ top soil overlying gravel containing more than $2 \%$ of stones (Minchin et al. 2011). The site came out of 'Conquest' wheat in February 2011 and more than 5 years of pasture before that. The site was sprayed twice with Roundup $360^{\circledR}$ applied at 3 litres/ha, equivalent to $1080 \mathrm{~g}$ glyphosate/ha, before direct drilling the lucerne on 10 March 2011and the ryegrass on 24 March 2011. Cultivars used and sowing rates were, respectively, '54V09' (Pioneer) and $14 \mathrm{~kg} / \mathrm{ha}$ for the lucerne and, 'Samson' (AGRICOM) and $25 \mathrm{~kg} / \mathrm{ha}$ for the ryegrass. Two $t / h a$ of pelleted lime were applied (broadcasted) after drilling to the lucerne to raise the $\mathrm{pH}$ from initial values of 5.4. Lime was applied five more times at 


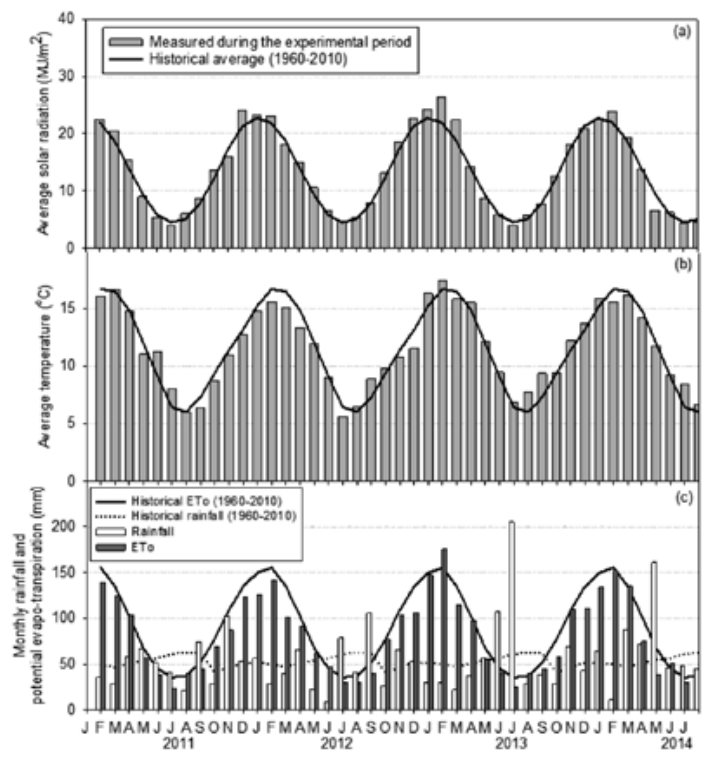

Figure 1

(a) Monthly average solar radiation from January 2011 to July 2014 at Broadfields weather station (black curve represents historical average (19602010)). (b) Monthly average temperature from January 2011 to July 2014 at Broadfields weather station (black curve represents historical average (1960-2010)). (c) Monthly average rainfall (white bars) and PET (grey bars) from January 2011 to July 2014 at Broadfields weather station (black curve represents historical average (1960-2010)).

6-8 months interval and $200 \mathrm{~kg} / \mathrm{ha}$ during the 3 years of experimentation. All crops received base mineral fertilisation (N, P, K, S and micronutrients) based on previous soil analysis in early spring. Ryegrass received applications of $\mathrm{N}$ after each harvest. Lucerne received applications of 155,30 and $95 \mathrm{~kg} \mathrm{~K} / \mathrm{ha}$ during year 1 , 2 and 3 respectively. Agrichemicals were applied to minimise pests and diseases pressure throughout the experimental period. Of note, was a winter application (June 2012) of 3 litres/ha of Roundup $360^{\circledR}$, equivalent $1080 \mathrm{~g} / \mathrm{ha}$ glyphosate, on lucerne plots to manage white clover and dandelion invasion. The experiment was conducted over 3 years (March 2011-May 2014).

Rainfall, Penman potential evapotranspiration (PET), and temperature data for the period of the experiment (March 2011-April 2014) were recorded at Broadfields meteorological station, accessed from the NIWA website (Figure 1). The weather station was $400 \mathrm{~m}$ south of the experimental site.

\section{Experimental design}

The experiment was set up as a latinised row by column design with four replicates of eight treatments: two crops, lucerne and ryegrass; and four different irrigation managements: (T1) replacement of water use twice a week, (T2) replacement of WU every fortnight, (T3) replacement of WU every 3 weeks, (T4) nil irrigation (rain fed only). For the first year of the experiment, T2 was replacement of WU weekly and T3 was replacement of water use fortnightly. After a preliminary analysis of the yield differences between treatments, it was decided to increase the period between irrigation events between T1, T2 and T3 to better understand the impact of irrigation frequency on the growth of those crops.

\section{Application of irrigation treatments}

Irrigation was applied to each plot independently using drip lines spaced $0.3 \mathrm{~m}$ apart.

During the first year of the experiment, irrigation requirements for each treatment were calculated using Penman's PET data recorded at Broadfields meteorological station, accessed from NIWA website. The amount of irrigation applied for a given treatment was equal to the sum of daily PET values minus rainfall for the period between irrigation events for that treatment.

From the second year of the experiment (November 2012) onwards, irrigation requirement (the proxy for WU) for each treatment was calculated (Equation 1) from volumetric soil moisture content (SMC) measured in the top $0.3 \mathrm{~m}$ of soil in each plot. Soil below this depth was not considered because of the very low WHC of the gravels below this depth. Field capacity of the top layer was assumed at $32.5 \%$ based on the highest SMC reading from the first year of experimentation. The targeted refill soil moisture content (RSMC) was set to SMC of $27 \%$ to minimise risk of water loss through drainage.

Irrigation requirement $(\mathrm{mm})$

$=(\mathrm{RSMC}-\mathrm{SMC}) \times 300(\mathrm{~mm})$

Table 1 shows the yearly amount of irrigation and rainfall received by each treatment during the 3 years of experimentation.

\section{Harvest management}

Dry matter (DM) production was measured at the end of each regrowth period using a small plot forage harvester (CIBUS Forage Chopper). Crops were defoliated at intervals of 4-8 weeks at $500 \mathrm{~mm}$ height. Ryegrass and lucerne were defoliated eight and five times, respectively, during year 1; eight and six times, respectively, during season 2; and eight and five times, respectively, during season 3 . After harvest, nitrogen, in the form of urea, was applied to the ryegrass treatments in proportion to the amount of biomass harvested from that treatment as suggested by Gastal \& Lemaire (2002). Nitrogen fertiliser applications were, for T1 to T4 respectively: 696, 679, 665 and $464 \mathrm{~kg} \mathrm{~N} / \mathrm{ha}$ during 
season 1; 649, 591, 512 and $347 \mathrm{~kg} \mathrm{~N} /$ ha during season 2; and 443, 417, 382 and $239 \mathrm{~kg} \mathrm{~N} /$ ha during season 3. The lucerne crop received 150,30 and $95 \mathrm{~kg} \mathrm{~N} / \mathrm{ha}$ during year 1, 2 and 3 respectively.

\section{Measurements}

\section{Biomass production}

Total above-ground biomass measurements from each harvest were taken from a 5-7 $\mathrm{m}$ long and 8 rows wide area $\left(6-8 \mathrm{~m}^{2}\right.$ area) using the forage harvester. A subsample of constant weight from each plot was then dried in a forced-fan oven at $90^{\circ} \mathrm{C}$ for $24 \mathrm{~h}$ and weighed to measure the DM content.

\section{Soil water content}

Volumetric water soil content (SMC) was measured in the top $0.3 \mathrm{~m}$ of soil in each plot using two water content reflectometers (Campbell Scientific ${ }^{\mathbb{R}}$, model CS 616) installed at $0-0.15 \mathrm{~m}$ and $0.15-0.3 \mathrm{~m}$ depths connected to a data logger (Campbell Scientific ${ }^{\mathbb{R}}$, model CR1000).

For the 0.3-1.5 $\mathrm{m}$ depth, SMC was measured fortnightly for each plot from at $0.2 \mathrm{~m}$ intervals $(0.1$ $\mathrm{m}$ for the first and the last depths, respectively $0.3-0.4$ $\mathrm{m}$ and $1.4-1.5 \mathrm{~m}$ ) using a neutron probe (CPN, model 503DR Hydroprobe).

\section{Calculations}

\section{Water use}

The water content of the $1.5 \mathrm{~m}$ soil profile (PSWC) was calculated at the date of each neutron probe measurement by multiplying the SWC of each layer $(\%)$ by the layer's depth (mm) and summing water content in all layers.

Table 1 Amount of irrigation applied per treatment $(\mathrm{mm})$ and yearly rainfall $(\mathrm{mm})$ during the 3 years of experimentation. For each treatment, both crops received the same amount of irrigation.

\begin{tabular}{|c|c|c|c|}
\hline Year & Treatment & $\begin{array}{l}\text { Irrigation applied } \\
\qquad(\mathrm{mm})\end{array}$ & $\begin{array}{c}\text { Rainfall } \\
(\mathrm{mm})\end{array}$ \\
\hline \multirow[t]{4}{*}{1} & $\mathrm{~T} 1$ & 390.4 & 593.6 \\
\hline & T2 & 363.4 & \\
\hline & T3 & 369.9 & \\
\hline & $\mathrm{T} 4$ & 0 & \\
\hline \multirow[t]{4}{*}{2} & $\mathrm{~T} 1$ & 490 & 829.1 \\
\hline & $\mathrm{T} 2$ & 353 & \\
\hline & T3 & 318 & \\
\hline & $\mathrm{T} 4$ & 0 & \\
\hline \multirow[t]{4}{*}{3} & $\mathrm{~T} 1$ & 293 & 633.4 \\
\hline & $\mathrm{T} 2$ & 261.6 & \\
\hline & T3 & 191.2 & \\
\hline & $\mathrm{T} 4$ & 0 & \\
\hline
\end{tabular}

The PSWC change ( $\triangle \mathrm{PSWC}$ ) over each measurement period was calculated as the difference of profile content at the beginning of the period less that at the end of the period.

The crop water use (WU) (mm) was then calculated from a water balance (Equation 2)

$\mathrm{WU}(\mathrm{mm})$

$=\Delta \mathrm{PSWC}+$ irrigation $(\mathrm{mm})+$ rainfall $(\mathrm{mm})$

Water use calculated by equation 2 includes crop transpiration, soil evaporation and drainage.

The water use efficiency (WUE) was calculated using WU and biomass production measurements (Equation 3).

WUE $(\mathrm{kg} \mathrm{DM} / \mathrm{mm})=$ Yield $(\mathrm{kg} \mathrm{DM}) / \mathrm{WU}(\mathrm{mm})$

\section{Statistical analyses}

Data were analysed by Analysis of Variance (ANOVA) using GenStat (14th Ed, VSN International Ltd). An indication of the variability associated with the calculated means is provided by the least significant difference (LSD) $(\alpha=0.05)$ for the interaction between the treatments.

\section{Results}

\section{Total above ground dry matter yield}

Year 1

Ryegrass under frequent irrigation (T1) had the highest annual biomass production during the first year of experimentation $(\mathrm{P}=0.09)$ at around $23.8 \mathrm{t} \mathrm{DM} / \mathrm{ha}$ (Figure 2a).

Under each irrigation treatment, lucerne had the lowest annual biomass production $(\mathrm{P}=0.09)$ at around $10.4 \mathrm{t} \mathrm{DM} /$ ha under frequent irrigation (T1), down to $2.8 \mathrm{t} \mathrm{DM} /$ ha without irrigation (T4) (Figure 2a).

Annual biomass production was the lowest under T4 for both crops at 13.8 and $2.8 \mathrm{t} \mathrm{DM}$ /ha for ryegrass and lucerne respectively.

\section{Year 2}

Annual biomass production was highest for both crops $(\mathrm{P}=0.002)$ under the most frequent irrigation treatment (T1) at around $18.6 \mathrm{t} \mathrm{DM} /$ ha (Figure $2 \mathrm{~b}$ ).

Biomass production of both crops declined with less frequent irrigation ( $\mathrm{P}=0.002)$ to 13.5 and $14.9 \mathrm{t} \mathrm{DM} /$ ha for ryegrass and lucerne, respectively, under T3 (Figure 2b).

Annual biomass production was lowest for both crops $(\mathrm{P}=0.002)$ under the treatment with no irrigation (T4). For that treatment, ryegrass biomass production was higher than that of lucerne $(\mathrm{P}=0.002)$ at 8.2 and 4.6 t DM/ha, respectively.

Year 3

Annual biomass production of ryegrass declined with 

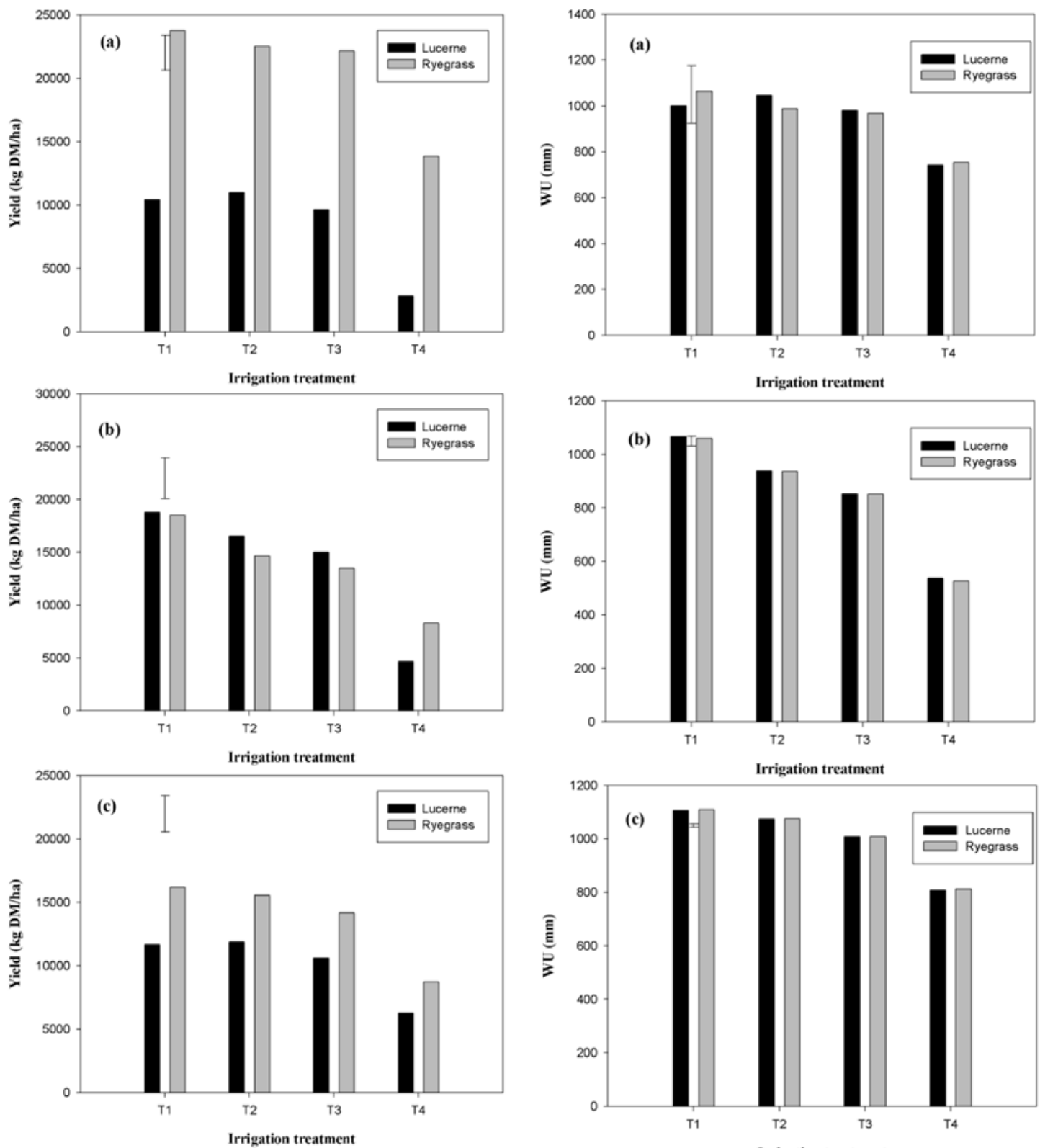

Figure 2 Annual above ground biomass yield (kg DM/ha) of lucerne and ryegrass under four different irrigation regimes: replacement of water use (WU) twice a week (T1), replacement of WU every fortnight (T2), replacement of WU every 3 weeks (T3), and nil irrigation (T4). (a) First year after sowing. (b) Second year after sowing. (c) Third year after sowing. Bar represents $\operatorname{LSD}(\mathrm{df}=21, \mathrm{a}=0.05)$.

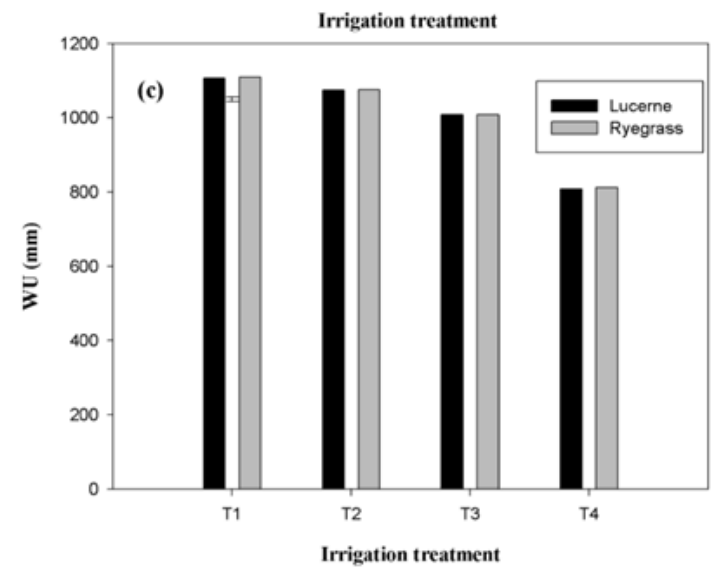

Figure 3 Annual water use $(\mathrm{mm})$ of lucerne and ryegrass under four different irrigation regimes: replacement of water use (WU) twice a week (T1), replacement of WU every fortnight (T2), replacement of WU every 3 weeks (T3), and nil irrigation (T4). (a) First year after sowing. (b) Second year after sowing. (c) Third year after sowing. Bar represents LSD $(d f=21, a=0.05)$.

less frequent irrigation $(\mathrm{P}<0.001)$ from 16.2 to $14.2 \mathrm{t}$ $\mathrm{DM} / \mathrm{ha}$ for $\mathrm{T} 1$ and $\mathrm{T} 3$ respectively (Figure $2 \mathrm{c}$ ).

Lucerne had an annual biomass production of 11.8 $\mathrm{t} \mathrm{DM} /$ ha under T1 and T2, and 10.6 t DM/ha under T3 (Figure 2c).

Both crops had their lowest annual biomass production under $\mathrm{T} 4$ with 8.7 and $6.3 \mathrm{t} \mathrm{DM} / \mathrm{ha}$ for ryegrass and lucerne respectively (Figure $2 \mathrm{c}$ ).

Ryegrass produced more annual biomass than lucerne under every treatment $(\mathrm{P}<0.001)$. 


\section{Water use and water use efficiency \\ Yearl}

Annual water use of both crops was similar for each treatment $(\mathrm{P}=0.994)$ and was the highest under $\mathrm{T} 1$ at around 1000-1050 $\mathrm{mm}$ (Figure 3a). It was the lowest under T4 at around $750 \mathrm{~mm}$.

Ryegrass had an annual water use efficiency higher than that of lucerne $(\mathrm{P}<0.001)$ under every treatment (Figure 4a). WUE of ryegrass ranged from $22.8 \mathrm{~kg}$ $\mathrm{DM} / \mathrm{mm}$ under T1 to $18.5 \mathrm{~kg} \mathrm{DM} / \mathrm{mm}$ under T4. WUE of lucerne ranged from $10.5 \mathrm{~kg} \mathrm{DM} / \mathrm{mm}$ under T1 to $3.8 \mathrm{~kg} \mathrm{DM} / \mathrm{mm}$ under T4. Both crops had their lowest WUE under T4.

\section{Year 2}

Annual WU of both crops was similar under each of the irrigation treatment $(\mathrm{P}=0.191)$ and was the highest under T1 at around $1064 \mathrm{~mm}$ (Figure 3b). WU declined with less frequent irrigation: $938 \mathrm{~mm}$ under T2, 853 mm under T3 and $532 \mathrm{~mm}$ under T4.

Both crops had similar WUE under T1, T2 and T3 at around $17.5,16.7$ and $16.7 \mathrm{~kg} \mathrm{DM} / \mathrm{mm}$ respectively (Figure $4 \mathrm{~b}$ ), but ryegrass had a higher WUE than lucerne under T4 $(\mathrm{P}<0.001)$ at 15.7 and $8.6 \mathrm{~kg} \mathrm{DM} / \mathrm{mm}$ respectively.

\section{Year 3}

Both crops had similar annual WU $(\mathrm{P}=0.228)$ under each treatment (Figure 3c). Annual WU declined with less frequent irrigation: from $1108 \mathrm{~mm}$ under $\mathrm{T} 1$ to 1075,1008 and $810 \mathrm{~mm}$ under T2, T3 and T4 respectively.

WUE under T1, T2 and T3 was similar for each crop (Figure 4c), but ryegrass had a higher WUE than lucerne $(\mathrm{P}<0.001)$ at 14.3 and $10.7 \mathrm{~kg} \mathrm{DM} / \mathrm{mm}$ respectively.

Both crops showed a lower WUE under T4 $(\mathrm{P}<0.001)$ at 10.7 and $7.8 \mathrm{~kg} \mathrm{DM} / \mathrm{mm}$ for ryegrass and lucerne respectively.

\section{Discussion}

The range of lucerne yields observed in this study (3-11 $\mathrm{t} / \mathrm{ha}$ for year $1,5-18 \mathrm{t} / \mathrm{ha}$ for year 2 and $6-12 \mathrm{t} / \mathrm{ha}$ for year 3$)$ is consistent with irrigated (9.4-14.0 t/ha) and dryland (3.6-11.1) lucerne yields reported on shallow soils (Douglas 1986). These yields are well below the reported potentials for high water holding capacity soils in Canterbury. For example, on a Wakanui deep silt loam soil at a nearby site, yields of $20-28 \mathrm{t} \mathrm{DM} /$ ha have been reported for irrigated lucerne (Brown \& Moot 2004; Teixeira et al. 2008; Teixeira et al. 2007). Dryland lucerne crops have been reported to yield 13$21 \mathrm{t} \mathrm{DM} /$ ha (Brown et al. 2005; Mills \& Moot 2010; Mills et al. 2008).

Ryegrass yields (14-24 t/ha for year $1,8-18 \mathrm{t} / \mathrm{ha}$ for year 2, 9-16 t/ha for year 3) were limited by water supply in this study. This is supported by previous yield
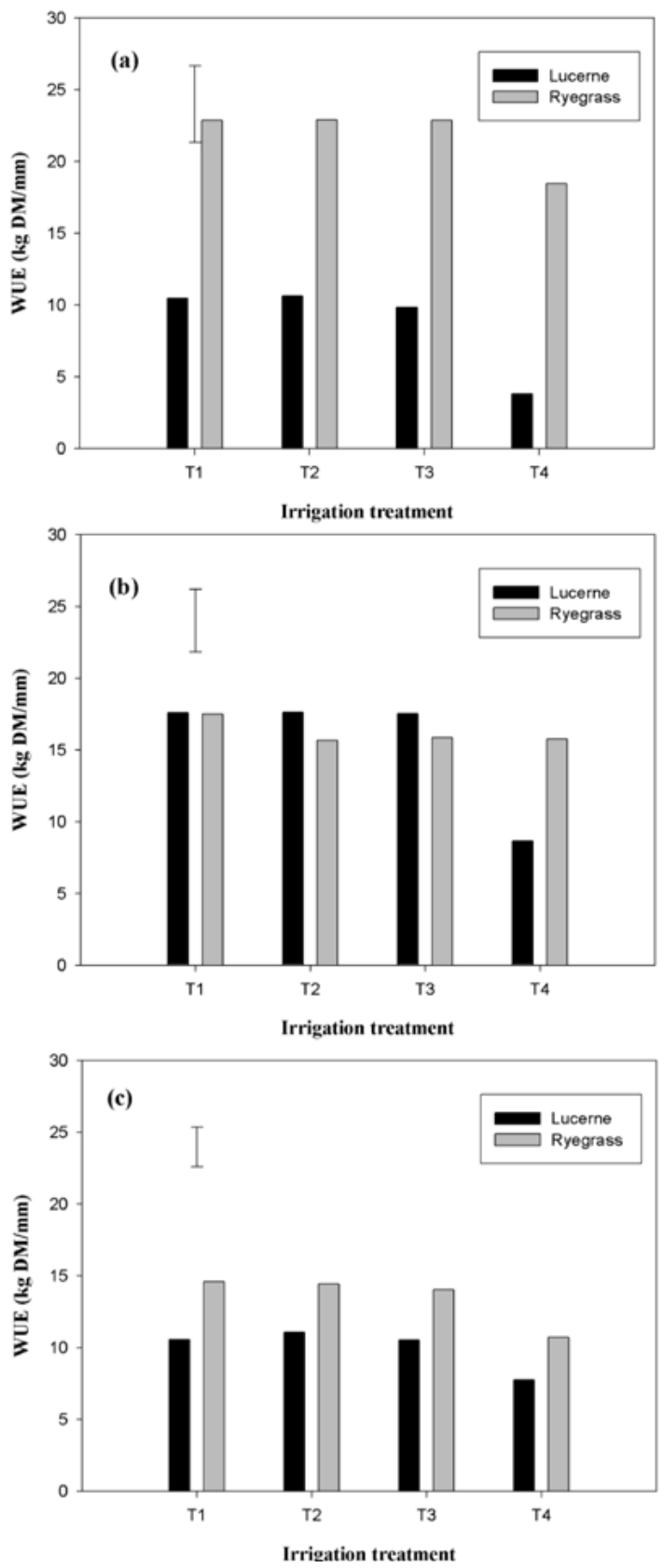

Figure 4 Annual water use efficiency ( $\mathrm{kg} \mathrm{DM} / \mathrm{mm}$ ) of lucerne and ryegrass under four different irrigation regimes: replacement of water use (WU) twice a week (T1), replacement of WU every fortnight (T2), replacement of WU every 3 weeks (T3), and nil irrigation (T4). (a) First year after sowing. (b) Second year after sowing. (c) Third year after sowing. Bar represents $\operatorname{LSD}(\mathrm{df}=21, \mathrm{a}=0.05)$.

reports for Canterbury ranging from 6 to 11 tha under dryland conditions (Mills \& Moot 2010; Mills et al. 2008). While ryegrass and lucerne yields were within 
reported ranges, the relative production of lucerne and ryegrass was unexpected. In general ryegrass yielded as much or more than lucerne where other studies show a production advantage for lucerne (Douglas 1986). The low yields for lucerne during the first year of experimentation were expected because it was the establishment season for the crop.

There was a rapid and unexpected decline evident in the production of the irrigated lucerne stands in this trial with substantial weed invasion and unhealthy looking plants evident by the end of year 3 (Field observations). Lucerne represented $59 \%$ of the botanical composition of the plots under the fully irrigated treatment versus $89 \%$ under the dry treatment (data not shown). Irrigation is expected to hasten the decline of lucerne stands through a reduction in plant population and increase in weed invasion (Brown et al. 2005). However Brown et al. (2005) showed only significant stand decline by the end of year 6 on a heavier soil (which would be expected to decline faster). While the exact cause could not be determined, the unhealthy appearance and unexpectedly poor production of irrigated lucerne in this trial suggests there was some site specific disease problem and these results should be treated with caution. It is also important to note that ryegrass needed between 700 and $250 \mathrm{~kg} \mathrm{~N} /$ ha, depending on the irrigation treatment, to be applied in each year to produce its yields.

Under dry conditions and no irrigation, the lucerne stand was healthy but ryegrass still yielded more than lucerne. This contrasts with deep soil conditions in which lucerne was shown to consistently yield more than ryegrass in New Zealand (Avery et al. 2008; Brown et al. 2006; Moot 2012). The dryland yield advantage of lucerne is usually attributed to its deeper tap root system that enables access to additional water supply when compared with the shallow fibrous root system of ryegrass (Moot et al. 2008). However, the shallow and stony soil in our study (Minchin et al. 2011) provided limited additional water for the crop to take up in the deeper soil layers. Also, the contrasting growth strategies of these two crops, regarding seasonality of growth rates, help explain the lower yield and WUE of dryland lucerne in shallow soils. Ryegrass biomass production is greater during cooler periods (spring and autumn), when the cool temperatures enable higher water use efficiency (Tanner \& Sinclair 1983), while lucerne biomass production is greater during the summer months when warmer conditions reduce water use efficiency. Some additional yield would be expected from the lucerne crops sprayed in June with glyphosate, but these showed visual leaf damage and slow early spring regrowth. Nevertheless, these results agree with previous reports showing that lucerne's comparative advantage over ryegrass is not evident in exceptionally dry years in Canterbury (Hayman 1985).

\section{Conclusion}

Under irrigation on a shallow soil, and a supply of $\mathrm{N}$ through fertilisation (250-700 kg N/ha), ryegrass yielded more that lucerne in the establishment year, which is expected. Yields were similar in the following year and lucerne yields declined below ryegrass in the third year. The unexpectedly rapid decline in lucerne production appeared to be due to disease and weeds limiting the production of irrigated plants. Ryegrass also yielded more than lucerne under dryland conditions on a shallow soil which was attributed to the greater cool season growth of ryegrass and the stony sub-soil meaning lucerne received no summer yield advantage from its deep tap root.

\section{ACKNOWLEDGMENTS}

This research was funded by The New Zealand Institute for Plant \& Food Research Limited through the Land Use Change and Intensification Programme (LUCI).

\section{REFERENCES}

Avery, D.; Avery, F.; Ogle, G.I.; Wills, B.J.; Moot, D.J. 2008. Adapting farm systems to a drier future. Proceedings of the New Zealand Grassland Association 70: 13-18.

Brown, H.E.; Moot, D.J. 2004. Quality and quantity of chicory, lucerne and red clover production under irrigation. Proceedings of the New Zealand Grassland Association 66: 257-264.

Brown, H.E.; Moot, D.J.; Lucas, R.J.; Smith, M. 2006. Sub clover, cocksfoot and lucerne combine to improve dryland stock production. Proceedings of the New Zealand Grassland Association 68: 109115.

Brown, H.E.; Moot, D.J.; Pollock, K.M. 2005. Herbage production, persistence, nutritive characteristics and water use of perennial forages grown over 6 years on a Wakanui silt loam. New Zealand Journal of Agricultural Research 48: 423-439.

Douglas, J.A. 1986. The production and utilization of lucerne in New Zealand. Grass and Forage Science 41: 81-128.

Gastal, F.; Lemaire, G. 2002. N uptake and distribution in crops: an agronomical and ecophysiological perspective. Journal of Experimental Botany 53: 789-799.

Hayman, J.M. 1985. The effect of irrigation interval and soil type on pasture and lucerne production. Proceedings of the New Zealand Grassland Association 46: 15-23.

Mills, A.; Moot, D.J. 2010. Annual dry matter, metabolishable energy and nitrogen yields of six dryland pastures six and seven years after establishment. Proceedings of the New Zealand Grassland Association 72: 177-184. 
Mills, A.; Smith, M.C.; Lucas, R.J.; Moot, D.J. 2008. Dryland pasture yields and botanical composition over 5 years under sheep grazing in Canterbury. Proceedings of the New Zealand Grassland Association 70: 37-44.

Minchin, R.; Fletcher, A.L.; Gillespie, R.; George, M.; Meenken, E.D.; Shorter, S.; Brown, H.E. 2011. Yield and quality of milling wheat in response to water deficit and sowing date on a shallow soil. Agronomy New Zealand 41: 49-58.

Moot, D.J. 2012. An overview of dryland legume research in New Zealand. Crop and Pasture Science 63: 726 .

Moot, D.J.; Brown, H.E.; Pollock, K.; Mills, A. 2008. Yield and water use of temperate pastures in summer dry environments. Proceedings of the New Zealand Grassland Association 70: 51-57.

Moot, D.J.; Mills, A.; Pollock, K. 2010. Natural resources for Canterbury agriculture. Proceedings of the New Zealand Grassland Association 72: IXXVII.

Salinger, J. 2003. Climate reality - actual and expected. Legumes for Dryland Pastures. Grassland Research and Practice Series 11: 13-18.

Sheaffer, C.C.; Tanner, C.B.; Kirkham, M.B. 1988. Alfalfa water relations and irrigation. American Society of Agronomy, Crop Science Society of America, Soil Science Society of America, Madison, Wisconsin. pp. 373-409.
Tanner, C.B.; Sinclair, T.R. 1983. Efficient water use in crop production: research or re-search? pp. 1-27. In: Limitations to efficient water use in crop production. Eds. Taylor, H. M.; Wayne, J. R.; Thomas, S. R. American Society of Agronomy, Crop Science Society of America, Soil Science Society of America, Madison, WI.

Teixeira, E.I.; Moot, D.J.; Brown, H.E. 2008. Defoliation frequency and season affected radiation use efficiency and dry matter partitioning to roots of lucerne (Medicago sativa L.) crops. European Journal of Agronomy 28: 103-111.

Teixeira, E.I.; Moot, D.J.; Brown, H.E.; Fletcher, A.L. 2007. The dynamics of lucerne (Medicago sativa L.) yield components in response to defoliation frequency. European Journal of Agronomy 26: 394400.

White, J.G.H. 1982. Lucerne grazing management for the 80s. Pp. 111-114 In: Lucerne for the 80s. Ed. Wynn-Williams, R.D. Special Publication No. 1, Agronomy Society of New Zealand 